\title{
Hematological and blood metabolite response in relation to the conception rate of Pasundan cows with synchronized estrous and ovulation
}

\author{
E. N. Setiawati ${ }^{1}$, M. Y. Sumaryadi ${ }^{2}$ and D. M. Saleh ${ }^{2}$ \\ ${ }^{1}$ Cinagara Animal Health Training Center, Jl. Snakma Desa Pasir Buncir, Kecamatan Caringin, \\ Kabupaten Bogor, West Java - Indonesia \\ ${ }^{2}$ Faculty of Animal Science, Jenderal Soedirman University, \\ Jl. Prof. Dr. H.R. Boenyamin No. 708, Grendeng, Purwokerto, Central Java - Indonesia \\ Corresponding E-mail: e.niasetiawati@gmail.com \\ Received June26, 2020; Accepted October 12, 2020
}

\begin{abstract}
ABSTRAK
Dua puluh ekor induk sapi Pasundan digunakan dalam penelitian ini bertujuan untuk mengetahui hubungan antara hematologis dan metabolit darah dengan tingkat kebuntingan sapi Pasundan yang disinkronisasi Estrus dan Ovulasi. Sapi dibagi menjadi dua perlakuan, 1) diserentakan berahinya dengan injeksi ganda PGF2 $\alpha$ dosis $5 \mathrm{ml}, 2$ ) kombinasi hormon PGF2 $\alpha$ dengan GnRH sebanyak $2.5 \mathrm{ml}$ per ekor secara intramuskulair. Sapi yang berahi dilakukan inseminasi buatan sebanyak $2 \mathrm{x}$ dengan selang waktu 6 jam. Peubah yang diamati berupa persentase estrus angka kebuntingan, $\beta$-hydroxy butyric acid (BHBA), blood urea nitrogen (BUN), dan non esterificated acid (NEFA). Data diolah dengan analisis variansi dan regresi korelasi. Hasil penelitian menunjukkan bahwa angka kebuntingan kombinasi prostaglandin dengan GnRH lebih baik dari injeksi ganda prostaglandin (70\% vs 60\%), rataan kadar eritrosit, leukosit, hemoglobin, NEFA, BUN dan BHBA, berturut-turut $6.61 \pm 0.19$ million/ $\mu 1,11.30 \pm 0.35$ thousand/ $\mu 1,10.63 \pm 0.35 \mathrm{~g} / \mathrm{dL}, 1.65 \pm 018 \mathrm{mmol} / \mathrm{L}, 10.28 \pm 1.5 \mathrm{mg} / \mathrm{dL}, 21.46 \pm 1.96 \mathrm{mg} / \mathrm{dL}$. Hasil analisis regresi menunjukkan konsentrasi eritrosit, leukosit, hemoglobin, NEFA, BUN dan BHBA memiliki hubungan nyata $(\mathrm{P}<0.05)$ dengan kebuntingan dan koefisien determinasi masing-masing adalah $86.4 \%, 69.1 \%, 98.3 \%,-11.7 \%,-8.2 \%,-7.0 \%$. Disimpulkan bahwa kebuntingan memiliki hubungan yang kuat dengan hematologis, sedangkan dengan metabolit darah memiliki hubungan yang lemah dan berbanding terbalik.
\end{abstract}

Kata kunci : Sapi Pasundan, sinkronisasi, Angka kebuntingan, Hematologis, metabolit darah

\begin{abstract}
Twenty pasundan cows were divided into two treatments int his study aims to determine the correlation between hematological and blood metabolite on the conception rate of Pasundan cows with synchronized estrus and ovulation. Twenty pasundan cows were divided into two treatments 1) estrus synchronization through double injection $5 \mathrm{ml} \mathrm{PGF} 2 \alpha, 2)$ combination of $5 \mathrm{ml}$ PGF2 $\alpha$ per cow and 2.5 $\mathrm{ml}$ GnRH per cow intramuscularly. The heat of cow is immediately inseminated 2 times with an interval of 6 hours. The observed variables were estrus percentage, conception rate, erythrocyte, leucocyte, hemoglobin, $\beta$-hydroxy butyric acid (BHBA), blood urea nitrogen (BUN), and non esterificated acid (NEFA). Data were processed by analysis of variance and correlation- regression. The result showed that
\end{abstract}


PGF2 $\alpha$ with GnRH injection resulted in a better conception rate than that of PGF2 $\alpha(70 \%$ vs $60 \%)$, the average plasma concentration of erythrocyte, leucocyte, hemoglobin, NEFA, BUN, and BHBA levels respectively was $6.61 \pm 0.19 \mathrm{million} / \mu \mathrm{l}, 11.30 \pm 0.35$ thousand $/ \mu \mathrm{l}, 10.63 \pm 0.35 \mathrm{~g} / \mathrm{dL}, 1.65 \pm 018 \mathrm{mmol} / \mathrm{L}$, $10.28 \pm 1.50 \mathrm{mg} / \mathrm{dL}, 21.46 \pm 1.96 \mathrm{mg} / \mathrm{dL}$. The data obtained were performed variance analysis and correlation regression analysis using SPSS 16.0. The results of the regression analysis showed that the concentration of erythrocytes, leucocytes, hemoglobin, NEFA, BUN, and BHBA had a significant relationship $(\mathrm{P}<0.05)$ with pregnancy, and coefficient of determination were $86.4 \%, 69.1 \%, 98.3 \%$, $-11.7 \%,-8.2 \%,-7.0 \%$, respectively. It was concluded that the pregnancy of Pasundan cows has a strong relation between the conception rates with hematological, however blood metabolites showed a weak relation and inversely proportional.

Keywords: Pasundan cows, Synchronization, Conception Rate, Hematological, Blood Metabolite.

\section{INTRODUCTION}

Factor that influenced the reproductive performance of Pasundan cows i.e. delayed estrus, abortion, reproductive disease etc. The common issue for farmers in Pameungpeuk, Garut District is the suboptimal reproduction function of Pasundan cows that causes a low birth rate. The predictive indicators of this suboptimal function include the low success rate of artificial insemination (AI), high silent estrus, and the long calving interval due to anestrus over three months after calving. The contributing factors to anestrus in cows include hormonal disorder, environmental changes, poor feed management, and disease (Prabowo, 2010). In addition, Pemayun (2009) stated that gonadotropin hormone treatment and improve the livestock manangement could be addressed to correct the anestrus disorder, silent heat and repeat

Two common ways of estrus induction using PGF $2 \alpha$ are single injection and double injection. An optimum conception rate is the goal of estrus synchronization (Efendi et al., 2015). Previous studies reported that the success rate to synchronize estrus using prostaglandin was higher in the double injection method than the single injection (Martins et al., 2011) and faster to lower P4 level and induced luteolysis (Nascimento et al., 2014). Also, Balumbi et al. (2019) reported that heat response using double injection was $90 \%$, better than $70 \%$ in the single injection. Sianturi et al. (2012), reported that an ovsynch method (GnRH-PGF-GnRH) on buffalo given a better result . on cows rather than heifers (66.7 vs. 62.5\%). Furthermore, Suartini et al. (2013) reported that inducing prostaglandin (PGF2 $\alpha$ ) and $\mathrm{GnRH}$ in the first AI resulted in a $25 \%$ conception rate of cow, while prostaglandin (PGF2 $\alpha$ ) and $\mathrm{GnRH}$ given on 11 days after AI resulted in $37.5 \%$ conception rate.
Templeman and Murphy (2018) stated that nutrition is crucial for physiological reproduction of livestock. Malnutrition would cause disorder in the synthesis and regulation of the reproductive hormone, which leads to an unclear response to estrus. Blood metabolite profile that includes Blood Urea Nitrogen (BUN), $\beta$-hydroxybutyric acid (BHBA), Non-esterified fatty acids (NEFA) are the important indicators of homeostasis mechanism that keeps blood parameter within the range of physiology despite different feed and maintenance (Gross et al., 2011). Measuring the metabolic parameter as well as nutrition and health status in one livestock group may identify any subclinical disorder and the contributing factor. Blood metabolite factor plays an important role in early identification of energy metabolism disorder in cows (Prodanovic et al., 2012). Khan et al. (2010) reported low blood glucose and total protein that caused disorder in the function of reproductive hormones and suboptimal function of the reproductive tract which leads to the failure development of follicle, oocyte, and embryo. Moreover, this condition could cause an early death of embryo and failure in fertilization which may cause repeat breeding (Khan et al., 2010). The highest urea in blood (BUN) suppresses uterus $\mathrm{pH}$, decreases the production of prostaglandin hormone, and affects the axis of hypophysis-pituitary-ovary. This condition causes a toxic effect in sperm, ovum, and embryo which leads to the declining reproductive function (Roy et al., 2011; Bindari et al., 2013). Triglycerides, protein, and glucose are part of the nutrients needed for fetal growth and development during pregnancy (Templeman and Murphy (2018).

A hematological examination is used to measure the health status of animals by analyzing the total red blood cell (erythrocyte), hemoglobin profile $(\mathrm{Hb})$, and hematocrit percentage (PCV) (Gerardo et al., 2009). In animals, the total 
hemoglobin is equal to the erythrocyte and hematocrit (Sonjaya, 2012). Sufficient nutrition in feed showed a normal total erythrocyte within the normal blood content (Adam et al., 2015). Meanwhile, Roland et al. (2014) stated that total leucocyte plays an important role in maintaining body defense which would increase when fighting infectious disease, intoxication, anaphylactic shock, and central nerve disorder.

This research was conducted to observe the success of the success of AI after estrus sync using double injection (PGF2 $\alpha$ - PGF2 $\alpha$ ) and ovulation synchronization using double prostaglandin injection and GnRH (PGF2 $\alpha$ GnRH - PGF2 $\alpha$ ), as well as the relation of blood metabolite and scheduled AI, and the relation of blood metabolite concentration and hematology on the conception rate of Pasundan heifers.

\section{MATERIALS AND METHOD}

\section{Location and selection of acceptor cattle}

The research used 20 Pasundan heifers.aged 2.0 - 2.5 years from farmers who joined farmer groups of Pasundan cows Rundayan Sawargi Group in Cihurang region, Karya Mukti village, Cibalong, Garut. The cows selected for the AI acceptor must have a body score condition (BCS) of 3 according to estimation BCS 1-5 (Alapati et al., 2010). All cattle were palpated per rectum to examine the reproduction status and to make sure that the cows were not conceived. The selected cows must be healthy, The selected cows were given an identification number and the data were recorded (owner, age, distinctive feature, and others).

\section{Materials and Equipment}

The equipment was 10-ml syringe, venojet, sahli pipette, stirring rods, haemometer, standard cylindrical glass, glass object, vacuum tube EDTA (Ethylene Diamine Tetraacetic Acid), microscope, counter, Sahli tube, capillary tube, centrifuge kit, Reader, hemoglobinometer and pipette drop as well as KIT BUN, BHBA, and NEFA, gloves, restrain cage and rope, artificial insemination kit and camera for gestation examination, and stationary. The materials used were prostaglandin hormone preparate (Lutalyse TM, dinoprost tromethamine, Upjohn, Kalmozoo, USA), gonadotropin-releasing hormone (Fertagyl, Intervet Animal Health UK Ltd, Cambridge), frozen semen of Pasundan cows derived from Artificial Insemination Instituton, Lembang, blood and serum of the experimental cattle, chemical substance to measure blood metabolite (KIT, Sigma Chemical Co., St Louis, MO). Hemoatological analysis used fresh blood sample, $70 \%$ alcohol, aquadest, dissolvent (Turk) and HC.

\section{Research Method and Design}

The study was conducted based on experimental methods designed into 2 (two) observational variable groups, namely the dependent variable $(\mathrm{Y})$ in the form of pregnancy rate and the independent variable $(\mathrm{X})$ in the form of hematological concentrations and blood metabolites. All experimental cows were fed basal feed (forage) and supplement feed that had been rationed according to the local environmental condition, while water was provided ad libitum. Twenty Pasundan cows were allocated to 2 (two) treatment groups, namely P1 where 10 cows were injected with $5 \mathrm{ml} /$ head prostaglandin (PGF2 $\alpha$ ) two times with an 11-day interval to synchronize the physiological condition of each cows as a control group 2. P2 was 10 cows treated with an intramuscular injection of $5 \mathrm{ml} /$ head prostaglandin (PGF2 $\alpha$ ) double injections with 11 days interval, on the 9th day was given an intramuscular injection of $2.5 \mathrm{ml} /$ head gonadotropin-releasing hormone $(\mathrm{GnRH})$.

\section{The Variables Observed}

1. The percentage of estrus cows referred to the total cows that experienced estrus symptoms divided by all cattle, times 100 .

2. Conception rate is the gestating Pasundan cows divided by total mating Pasundan cows, times 100, and expressed in percentage unit.

3. Hematological (erythrocyte, leucocyte, hemoglobin) concentration and blood metabolite profile which included Blood Urea Nitrogen (BUN), $\beta$-hydroxybutyric acid (BHBA), Non-esterified fatty acids (NEFA) were measured during conception examination on the $60^{\text {th }}$ day.

\section{Synchronization Treatment}

Twenty Pasundan cattle were allocated to 2 (two) treatment groups. Ten cows were synchronized by double prostaglandin intramuscular injection (Lutalyse TM, Upjohn, Kalmozoo USA containing $25 \mathrm{mg}$ Dinoprost Tromethamin), $5 \mathrm{ml} / \mathrm{head}$, two times a day with an 
11-day interval. On the $9^{\text {th }}$ day, the cows were injected intramuscularly with a $2.5 \mathrm{ml} /$ head gonadotropin-releasing hormone (Fertagyl, Intervet Animal Health UK Ltd, Cambridge; containing $100 \mu \mathrm{g}$ Gonadorelin which is $\mathrm{GnRH}$ synthetic). Cow hat experienced immediate estrus were employed for AI two times with a 6-hour interval from the first AI.

\section{Estrus Observation}

Estrus observation was performed two times a day in the morning $(06.00-08.00)$ and afternoon $(17.00-18.00)$ three days in a row after the last PGF2 $\alpha$ injection. The signs of estrus were observed from the cows' behavior, such as agitation, bellowing, mounting another cow by their side. Also, palpation per rectum were conducted to confirm the uterus tension and developing follicles.

\section{Conception Examination}

Two months after the AI, the anestrous cows would undergo a rectal palpation by palpating the uterus part to detect any swelling uterus during the gestation (Jainudeen and Hafez, 2008).

\section{Blood Collection and Preparation}

Blood was collected when the cows had conceived for 60 days. Blood plasma for measuring the blood metabolite and hematological was drawn from the vena jugularis using a $10 \mathrm{ml}$ venoject. The collected blood sample in reaction tube was placed in an ice-filled thermos when transfered to laboratory, let it sit for 30 minutesThen, the plasma was collected from the tube using a micropipette, into an Eppendorf tube, and stored in a freezer for hematological analysis.Blood metabolite analysis was conducted in an enzymatic technique using KIT (Sigma Chemical Co., St Louis, MO) with the available standard estimation.

\section{Blood Metabolite Examination}

The analysis of the Non-Esterified Fatty Acid (NEFA) level was conducted using a Max Discovery NEFA Assay Kit (Sigma Chemical Co., St Louis, MO). The wavelength was $550 \mathrm{~nm}$ for the standard or sample used. Analysis of Blood Urea Nitrogen (BUN) was conducted in an enzymatic technique using KIT (Sigma Chemical Co., St Louis, MO) with the available standard estimation. This parameter was analyzed using an Auto analyzer (Refloton (R) plus) by dropping one drop of blood $(30 \mu \mathrm{l})$ on the kit rod. Each parameter used a different kit rod and put it into the auto analyzer for a few minutes for automatic reading.

The level of $\beta$-hydroxybutyric acid (BHBA) was measured using an enzymatic KIT (Sigma Chemical Co., St Louis, MO) with the available standard estimation. BHBA level was measured using Precisian XtraTM Blood Test Strips. The test was 25 seconds per sample using one strip for each drop of blood.

\section{Haematological Examination}

The red blood cell (erythrocyte) was measured based on the total blood cell count using the Hayem method and expressed in unit per $\mathrm{mm}^{3}$ blood.The white blood cell (leucocyte) was measured based on the total leucocyte using Turk and expressed in unit per $\mathrm{mm}^{3}$ blood.Hemoglobin analysis was conducted by measuring total haemoglobin using the Sahli method, expressed in unit per mm3 blood. Principally, this method is converting hemoglobin into hematin acid, using a color standard in hemoglobinometer.

\section{Data Analysis}

The obtain data which included the percentage of estrus cattle and gestating cows were subject to a Chi-square analysis (Steel and Torrie, 1993) to observe the difference between the synchronized estrus treatments. The type and correlation between conception rate as the dependent variable $(\mathrm{Y})$ and hematological concentration and blood metabolite (X) were analyzed using a correlation regression in Microsoft Excel ${ }^{\circledR 2010}$ and SPSS16.

\section{RESULT AND DISCUSSION}

\section{Hematological Status}

The result of hematological status (erythrocyte, leucocyte and hemoglobin) and blood metabolite (Blood Urea Nitrogen /BUN, $\beta$ hydroxybutyric acid /BHBA, Non-esterified fatty acids /NEFA) are presented in Table 1.

Table 1 shows that the concentrations of erythrocyte, leucocyte, and hemoglobin of cows with a synchronized estrus (PGF2 $\alpha-P G F 2 \alpha$ ) and synchronized ovulation (PGF2 $\alpha-$ GnRH-PGF2 $\alpha$ ) are within the normal range. It was in line with Roland et al. (2014) that the normal range of total erythrocyte, leucocyte, and hemoglobin of cows was $4.9-10 \times 106 \mu \mathrm{l}, 5.0-16((\mathrm{k} / \mu \mathrm{l})$, and 8.4-14 $\mathrm{g} / \mathrm{dL}$, respectively. 
Table 1. Mean Concentration Levels of Haematological (Erythrocytes, Leucocytes and Hemoglobin) in 60 Days Pregnant in Pasundan Cows

\begin{tabular}{lcc}
\hline \multicolumn{1}{c}{ Variable } & Mean & Mean \\
& PGF2 $\alpha-$ PGF2 $\alpha$ & PGF2 $\alpha$-GnRH-PGF2 $\alpha$ \\
\hline Erythrocytes (million/ $\mu \mathrm{L})$ & $5.63 \pm 0.35$ & $6.61 \pm 0.19$ \\
Leucocytes (thousand/ $\mu \mathrm{l})$ & $11.29 \pm 0.3$ & $11.30 \pm 0.35$ \\
Hemoglobin $\mathrm{g} / \mathrm{dL}$. & $10.93 \pm 0.81$ & $10.63 \pm 0.35$ \\
\hline
\end{tabular}

Analysis of variance result showed that the synchronized estrus (PGF2 $\alpha-P G F 2 \alpha)$ and synchronized ovulation (PGF2 $\alpha-$ GnRH-PGF2 $\alpha$ ) did not significantly affect $(\mathrm{P}>0.05)$ the concentration of erythrocyte, leucocyte, and hemoglobin. Sufficient nutrition in feed would result in a normal level of total erythrocyte within the higher normal range of cow blood (Adam et al., 2015). Also, Roland et al. (2014) stated that total leucocyte plays a role in Body defense mechanism, and leucocyte performance would increase in handling viral infection, food poisoning, anaphylactic shock, and dysfunction central nervous system. Furthermore, Roland et al. (2014) mentioned the declining total leucocyte in cows could be attributed to the depleting leucocyte production, viral infection, acute inflammation, cytotoxic substance, bone marrow disorder, and others. Baldy (2003) stated that hemoglobin transports most of the oxygen and a smaller fraction of carbon dioxide and maintain normal blood pH. Furthermore. Baldy (2003) also mentioned that leucocytosis condition is the general physiological response to protect the body from a microorganism attack. On the other hand, leukopenia conditions (total leucocyte declines) may occur because of the ineffective formation process. The disorder of cell formation has been attributed to the administration of cytotoxic medicine, toxic substances, viral infection, hunger, and displacement of normal bone marrow by malignant cells as in leukemia (Baldy, 2003). The significant increase of leucocyte percentage may be due to chronic viral inflammation, insufficient adrenal cortex disorder, and physiological factors like fear, anxiety and pain (Vasconcelos and Galyean, 2014). The contributing factors to increasing leucocyte are chronic disease and an increase in steroids due to stress.
Hemoglobin $(\mathrm{Hb})$ value is significantly affected by nutrition sufficiency in the cattle, especially protein as the material for hemoglobin synthesis (Wardayanto, 2004). Meanwhile, Adam et al. (2015) stated that nutrition factors play a role in the concentration of hemoglobin in cows the more fulfilled the nutrition, the higher the normal range of hemoglobin in the blood. Furthermore, Santosa et al. (2014) stated that the increasing demand for $\mathrm{O}_{2}$ is required to maintain an intensive energy metabolism when the cattle are experiencing distress. Hemoglobin synthesis is affected by the nutrition content in a feed, such as protein and iron Martini (2009). Iron deficiency would decrease the hemoglobin level in blood under the normal range, which is known as anemia, and $99 \%$ of anemia is due to iron deficiency that decreases body immune and makes the body susceptible to disease (Allison, 2012).

The result showed that estrus synchronization (PGF2 $\alpha-$ PGF2 $\alpha$ ) and ovulation synchronization (PGF2 $\alpha-$ GnRH-PGF2 $\alpha$ ) did not cause leucocytosis, leukopenia, and anemic condition where the total erythrocyte and hemoglobin declined. Also, polycythemia as the parameter of an increasing total erythrocyte and hemoglobin level. The synchronized PGF2 $\alpha$ PGF $2 \alpha$ and PGF $2 \alpha-$ GnRH-PGF $2 \alpha$ was considered effective and efficient to be administered in Pasundan heifers.

\section{Blood Metabolite Level}

The result of blood metabolite analysis (Blood Urea Nitrogen /BUN, $\beta$-hydroxybutyric acid/BHBA, Non-esterified fatty acids /NEFA) is presented in Table 2. Table 2 shows that the concentration of blood metabolite includes Blood Urea Nitrogen (BUN) $\beta$-hydroxybutyric acid (BHBA), Non-esterified fatty acids (NEFA) of 
Table 2. The Average Concentrations of Blood Metabolites (NEFA, BHBA, BUN) in 60 days Pregnant in Pasundan Cows

\begin{tabular}{lcc}
\hline \multicolumn{1}{c}{ Variable } & Mean & Mean \\
& PGF2 $\alpha$-PGF2 $\alpha$ & PGF2 $\alpha$-GnRH-PGF2 $\alpha$ \\
\hline Non Esterified Fatty Acids (NEFA)(mmol L $\left.{ }^{-1}\right)$ & $1.88 \pm 0.56$ & $1.65 \pm 018$ \\
Beta Hydroxy Butirat Acid (BHBA) (mg dL-1) & $10.22 \pm 1.59$ & $10.28 \pm 1.50$ \\
Blood Urea Nitrogen (BUN) (mg dL-1) & $23,98 \pm 3.50$ & $21.46 \pm 1.96$ \\
\hline
\end{tabular}

Pasundan cows with a synchronized estrus (PGF2 $\alpha-\mathrm{PGF} 2 \alpha$ ) and synchronized ovulation were in the normal range. Julie et al. (2013) stated that the level of BHBA was above $9 \mathrm{mg} / \mathrm{dL}-1$ and the normal level of NEFA in cow was $0.26 \mathrm{mmol} \mathrm{L-1}$, but NEFA could increase up to $1 \mathrm{mmol}$ during gestation (Van Saun, 2000).

Furthermore, Meyer and Harvey (2004) reported that normal BUN was $6-27 \mathrm{mg} / \mathrm{dL}$. The analysis of variance result showed that the synchronized estrus (PGF2 $\alpha-\mathrm{PGF} 2 \alpha)$ and synchronized ovulation (PGF2 $\alpha-$ GnRH-PGF2 $\alpha$ ) did not significantly affect $(\mathrm{P}>0.05)$ the concentration of NEFA, BHBA and BUN. Blood metabolite is significantly affected by the amount of nutrition feed consumed by the cattle, and the contributing factors to blood metabolite include age, stress, health status, and other external factors (Prihatno et al., 2013).

NEFA blood is the indicator of cattle energy status, but NEFA concentration could be affected by stress. Accordingly, it is important to maintain nutrition status (Asl et al., 2011). Furthermore, Wahyudi (2008) stated that fertility success until conception and the improvThe Percentage of Estrus and Conception Rate after AI in Synchronized Pasundan Cows ing quality of estrus are related to BCS value. Malnutrition or deficient feed intake could directly affect reproduction efficiency (Suryahadi, 2003). Mean while, Adewuyi et al. (2005) reported that low blood glucose would increase high non-esterified fatty acids (NEFA) that induced toxic effect on the follicle, oocyte, embryo, and fetus as well as decreasing GnRH secretion by the hypothalamus. The decreased GnRH would obstruct FSH and LH synthesis in the anterior hypophysis, prevent follicle from developing, and leads to anestrus (Oguike and Okocha, 2008). Khan et al. (2010) reported that low blood glucose and total protein have caused disorder in the function of reproductive hormone that resulted in the failure development of follicle, oocyte and embryo. It was in line with Prihatno et al. (2013) that that high NEFA concentration imposed a toxic effect on the follicle, oocyte, embryo and fetus which is indicative of low energy (carbohydrate) in the ration. Saleh et al. (2011) stated that the imbalance protein content would disturb the secretion of gonadotropin hormone $(\mathrm{GnRH})$. The BUN level is affected by protein intake from feed and catabolism of body protein, while Blood Urea Nitrogen is the urea concentration in serum or plasma which is affected by nitrogen content as one of the main indicators of kidney function (Sennang et al., 2005). Pemayun (2009) reported that during dehydration, the total urea excreted by the body would decline; therefore, urea level in blood circulation increases, and the BUN level is indicative of glomerular filtration rate (GFR).

\section{Estrus Percentage and Conception Rate}

The results of the estrus percentage and conception rate are presented in Table 3. Table 3

Table 3. The Percentage of Estrus and Conception Rate after AI in Synchronized Pasundan Cows

\begin{tabular}{rcc}
\hline Variabel & PGF2 $\alpha$-PGF2 $\alpha$ & PGF2 $\alpha$ - GnRH-PGF2 $\alpha$ \\
\hline Persentase Estrus (\%) & 100 & 100 \\
Conception Rate (\%) & 60 & 70 \\
\hline
\end{tabular}


shows that synchronized estrus (PGF2 $\alpha-\mathrm{PGF} 2 \alpha$ ) and synchronized ovulation (PGF2 $\alpha$-GNRHPGF2 $\alpha$ ) showed an optimum result. All cows $(100 \%)$ showed noticeable estrus signs two days after the last PGF $2 \alpha$ injection. It was in line with Ribeiro et al. (2012) reported that in FH cows, the estrus percentage due to administering twice luteolytic dose of PGF $2 \alpha$ was $96,2 \%$. The high estrus percentage on the double injection may be due to the functional synchronized corpus luteum on the second injection (Ribeiro et al., 2012), therefore, the estrus response is higher and sync compared to the single injection. Also, Junior et al. (2016) reported that double injection of PGF2 $\alpha$ on the application of synchronized estrus in cows could well lysis CL so the level progesterone would altogether decline, and the estrus occurs simultaneously. The lysis corpus luteum would trigger estrus (Torres et al., 2013; Hassan et al., 2016). Besides, the other contributing factors to high estrus response in the double injection of PGF $2 \alpha$ are different individual factors in each treatment (Hassan et al., 2016). The analysis of variance result showed that estrus synchronization (PGF2 $\alpha-P G F 2 \alpha$ ) and ovulation synchronization (PGF2 $\alpha-P G F 2 \alpha$ ) did not significantly affect $(\mathrm{P}>0.05)$ the estrus percentage. Estrus cows would normally discharge clear, pure, and odorless mucus from the vulva (Lim et al., 2014). The amount and consistency of the mucus depend on the phase of the estrus cycle and the variation of hormonal rate (Vigil et al., 2009).

The percentage of conception rate with the synchronized ovulation (PGF2 $\alpha$-GnRH-PGF2 $\alpha$ ) was higher than that of synchronized estrus (PGF2 $\alpha-P G F 2 \alpha$ ). The administration of GnRH aims to sync the ovulation. The analysis of variance result showed that the synchronized estrus (PGF2 $\alpha-\mathrm{PGF} 2 \alpha$ ) and synchronized ovulation PGF $2 \alpha-P G F 2 \alpha$ did not significantly affect $(\mathrm{P}>0.05)$ the conception rate. On the ovsynch, the AI was performed 16-22 $\mathrm{h}$ after the second GnRH (Ali and Fahmy, 2007). Meanwhile, this study performed two AI to the estrus cattle with a 6-hour interval after the first AI. The high conception rate of Pasundan heifers in this research may due to the different types of cattle and a good condition of Pasundan cows receptor because the metabolite blood concentration and normal hematology were indicative of sufficient feed and proper reproduction function. The sufficient forage availability would decrease the first calving age and a sound response on the synchronized estrus.
De Rensis and Lopez-Gatius (2005) stated that besides cattle condition and feed sufficiency, the stage of estrus cycle (follicular or luteal ovarium) of the acceptor cattle of the PGF2 $\alpha$ and GnRH hormones was significantly affecting the efficiency of estrous synchronization protocol.

These results indicate that conception rate is inversely proportional to the concentration of blood metabolites. This means that the conception rate will be lower if the concentration of blood metabolites increases due to poor nutrition during pregnancy. This is because, the concentration of metabolites in the community if it occurs due to intake of negative nutrient balances resulting in the process of catabolism or an overhaul of food reserves from the body. On the ovsynch, the AI was performed 16-22 $\mathrm{h}$ after the second $\mathrm{GnRH}$ (Ali and Fahmy, 2007). Meanwhile, this study performed two AI to the estrus cattle with a 6hour interval after the first AI. The high conception rate of Pasundan heifers in this research may due to the different types of cattle and a good condition of Pasundan cows receptor because the metabolite blood concentration and normal hematology were indicative of sufficient feed and proper reproduction function. The sufficient forage availability would decrease the first calving age and a sound response on the synchronized estrus. Hassan et al., (2016) .condition and feed sufficiency, the stage of estrus cycle (follicular or luteal ovarium) of the acceptor cattle of the PGF2 $\alpha$ and GnRH hormones was significantly affecting the efficiency of estrous synchronization protocol. Furthermore, Lien, et al.,(2010) reported a strong correlation between reproduction and nutrition status, and malnutrition is the main obstacle of cattle reproduction in tropical areas. Malnutrition or insufficient nutrition intake could directly affect reproduction efficiency, such as low reproductive and production performance (Shaka et al., 2006).

Table 3 on regression analysis shows that the coefficient determination of hematological concentration (erythrocyte, leucocyte, and hemoglobin) is $>50 \%$, which is indicative of the significant influence of conception in Pasundan cows. This study showed that the hematological concentration is strongly correlated with the Pasundan cows' conception as indicated by the value of erythrocyte, leucocyte, and hemoglobin, namely $86.4 \%, 69.1 \%, 98.3 \%$, respectively. Furthermore, blood metabolite concentrations including $\beta$-hydroxy butyric acid (BHBA), blood urea nitrogen $(\mathrm{BUN})$, and non esterificated acid 
Table 4. The Relationship between Haematological Concentration (Erythrocytes, Leucocytes, Hemoglobin) and Blood Metabolites (BUN, NEFA, BHBA) With Pregnancy Rates of Pasundan cows

\begin{tabular}{lc}
\hline \multicolumn{1}{c}{ Variable } & Determinant Coefficient $(\%)$ \\
\hline Dependent Variable $(\mathrm{X}$, Conception Rate $(65 \%)$ & \\
& \\
Independent Variable & 86.4 \\
Erythrocytes (million/ $\mu \mathrm{L})$ & 69.1 \\
Leucocytes (thousand/ $\mu \mathrm{L})$ & 98.3 \\
Hemoglobin $(\mathrm{g} / \mathrm{dL})$ & -11.7 \\
Non Esterified Fatty Acid (NEFA)(mmol L-1) & -8.2 \\
Blood Urea Nitrogent (mg/dL) & -7.0 \\
Beta Hidroxy Butirat Acid (BHBA (mg/dL) & \\
\hline
\end{tabular}

(NEFA) were $(-7.0 \%),(-8.2 \%),(-11.7 \%)$. respectively showed low coefficient of determination $(<50 \%)$, have a weak relationship and inversely related to conception rate (Table 4).

\section{CONCLUSION}

In Pasundan cows, the ovysync (PGF2 $\alpha-$ GnRH-PGF2 $\alpha$ method) resulted higher conception rate in comparing with estrus sync (PGF2 $\alpha-P G F 2 \alpha$ ) i.e. $70 \%$ vs. $60 \%$. Concentration of erythrocytes, leucocytes, hemoglobin NEFA, BUN, and BHBA had a significant relationship $(\mathrm{P}<0.05)$ with pregnancy, and coefficient of determination were $86.4 \%, 69.1 \%, 98.3 \%$, $-11.7 \%,-8.2 \%,-7.0 \%$, respectively. It was concluded that the pregnancy of Pasundan cows has a strong relation between the conception rates with hematological, however blood metabolites showed a weak relation and inversely proportional.

\section{REFERENCES}

Adam, M., T.M. Lubis, B. Abdyad, N. Asmilia, Muttaqien and Fakhrurrazi. 2015. Jumlah Eritrosit dan Nilai Hematokrit Sapi Aceh dan Sapi Bali di Kecamatan Leumbah Seulawah Kabupaten Aceh Besar. Jurnal Medika Veterinaria. 9(2).

Adewuyi, A.A., E. Gruys and F.J.C.M. Van Eerdenburg. 2005. Non esterified fatty acids (NEFA) in dairy cattle. A Review, Veterinary Quarterly. 27(3):117-126.
Alapati, A., S.R. Kapa, S. Jeepalyam, S.M.P. Rangappa and K.R. Yemireddy. 2010. Development of the body condition score system in Murrah buffaloes: validation through ultrasonic assessment of body fat reserves. J. Vet. Sci. 11(1):1-8.

Allison. R.W. 2012. Laboratory evaluation of the liver di dalam Veterinary Hematology and Clinical Chemistry. Mary Anna Thrall, Glade Weiser, obin Allison, Terry W. Campbell. Lippincott Williams \& Wilkins. Maryland.

Ali, A. and S. Fahmy. 2007. Ovarian dynamics and milk progesterone concentrations in cycling and non-cycling buffalo- cows (Bubalus bubalis) during ovsynch program. Theriogenology. 68(1):23-28.

Asl, A.N., S. Nazifi, A.R. Ghasrodashti and A. Olyaee. 2011. Prevalence of subclinical ketosis in dairy cattle in the southwestern Iran and detection of cutoff point for NEFA and Glucose concentrations for diagnosis of subclinical ketosis. Preventive Vet. Med. 100(1):38-43.

Baldy, C.M. 2003. Gangguan Sel Darah Putih dan Sel Plasma dalam patofisiologis Konsep Klinis Proses-proses Penyakit. Editor: Price SA and Wilson LM. Jakarta: Penerbit Buku Kedokteran.

Bekuma, A. and H. Ketema. 2019. Estrus synchronization in Ethiopian dairy cattle: Principle, purpose and influencing factors. J. Anim. Husb. Sci. Technol. 1:1-4.

Bharali, M., P.M. Barua, B.C. Deka, D. Kalita, 
D.J. Dutta, D. Mili and K. Ahmed. 2014. Effect of GnRH analogue, PMSG and Progesterone on induction of oestrus in postpartum anoestrus Jersey Crossbred cows (Bos taurus). Int. J. Vet. Healt. Sci. Res. 2(6):31-33.

Bindari,Y. R., S. Shrestha, N. Shrestha and T.N. Gaire. 2013. Effects of nutrition on reproduction- a review. Adv Appl Sci Res. 4(1):421-429.

Balumbi, M., I. Supriatna and M.A. Setiadi. 2019. Respon and Characteristics of Estrous Synchronization with Cloprostenol in Friesian Holstein Cow. Acta Veterinaria Indonesiana. 7(1):29-36.

Chaikhun, T., T. Tharasanti, J. Rattanatep, F. De rensis and M. Techakumohu 2010. Fertility of swam buffalo following the synchronization of ovulation by the sequential administration GnRH and $\mathrm{PGF}_{2}$ alpha combine with fixed-timed artificial insemination. Theriogenology. 74:1371-1376.

De Rensis, F., G. Ronci, P. Guraneri, B.X. Nguyen, G.A. Presicce, G. Huszenicza, R.J. Scaramuzzi. 2005. Conception rate after fixed time insemination following ovsynch protocol with and without progesterone supplementation in cyclic and non-cyclic Mediterranean Italian buffaloes (Bubalus bubalis). Theriogenology. 63(7):1824-1831.

Efendi, M., T. Siregar, Hamdan, Dasrul, C. Thasmi, Razali, A Sayuti and B. Panjaitan. 2015. Angka kebuntingan sapi lokal setelah diinduksi dengan protokol ovsynch. Jurnal Medika Veteriner. 9(2):159 -162.

Gerardo, F.Q., J.L. Stephen, F.D. Todd, W. Darven, E.L. Ken and M.J. Robert. 2009. References limits for biochemical and hematological analyses of dairy cows one week before and one week after parturition. Can Vet J. 50(4):383-388.

Gross, J., H.A. Van Dorland, R.M. Brukmaier and F.J. Schwarz. 2011. Performance and metabolic profile of dairy cows during a lactational and deliberately induced negative energy balance with subsequent realimentation. J. Dairy Scie. 94(4):18201830.

Hassan, M., A. Husnain, M.I. Naveed, U. Riaz and N. Ahmad. 2016. Effect of ovsynch versusprostaglandinF2 $\alpha$ protocol on estrus response, ovulation rate, timing of ovulation and pregnancy per artificial insemination in Sahiwal cows. J. Anim. Scie. 88:445-450.

Jainudeen, M.R. and E.S.E. Hafez. 2008. Cattle and buffalo. Dalam Reproduction in Farm Animals. 7th Edition. Edited by Hafez E.S.E. Lippincott Williams \& Wilkins. Maryland. USA.159

Lim, H.J., J.K. Son, H.B. Yoon, K.S. Baek, T.I. Kim, Y. S. Jung and E. G. Kwon. 2014. Physical properties of estrus mucus in relation to conception rates in dairy cattle. J. Emb. Trans. 29(2): 157-161.

Lien, D. T. K., B. T. Nhung, N. C. Khan, L. T. Hop, N. T. Q. Nga, N. T. Hung, J. Kiers, Y. Shigeru, and R. Biesebeke. 2009. Impact of milk consumption on performance and health of primary school children in rural Vietnam. Asia Pac. J. Clin. Nutr. 18:326334.

Julie, M.H. and R.O. Thomas. 2013. Using physiological markers to defect health and production problems in transition dairy cows. WCDC Advance in Dairy Technology. 25:329-339.

Junior, M.V.C.F., A.V. Pires, M.V. Biehl, M.H. Santos, D.M. Polizel, D.D. Nepomuceno, R. Sartori, J.B.B. Filho, J.R.S. Goncalves and M.L. Day. 2016. Luteolysis in Bos indicus cows on Days 5 and 7 of estrous cycle with varying doses of PGF2 $\alpha$. Theriogenology. 86(5):1268-1274.

Khan, S., A. Thangavel and S. Selvasubramaniyan. 2010. Blood biochemical profile in repeat breeding cows. Tamilnadu J. Vet. Anim. Sci. 4: 90-102.

Martini. 2009. Indigenous Nguni and Crossbred Cattle in the Semi-arid Communal angelands in South Africa. Asian-Australas. J. Anim. Sci. 23(2): 213 - 225

Martins, J.P.N., R.K. Policelli, L.M. Neuder, W. Raphael and J.R. Pursley. 2011. Effects of cloprostenol sodium at final prostaglandin F2 $\alpha$ of Ovsynch on complete luteolysis and pregnancy per artificial insemination in lactating dairy cows. J. Dairy Sci. 94:28152824.

Meyer, D.J. and J. Harvey. 2004. Veterinary Laboratory Medicine Interpretation and Diagnosis. $3^{\text {rd }}$ Ed. . WB. Saunders. Philadelphia. P.225-236

Nascimento, A.B., A.H. Souza, A. Keskin, R. Sartori and M.C. Wiltbank. 2014. Lack of complete regression of the Day 5 corpus luteum after one or two doses of PGF $2 \alpha$ in 
nonlactating Holstein cows. Theriogenology. 81:389-395.

Oguike, M.O. and N.L. Okocha. 2008. Reproductive performance of rabbits remated at different intervals post-partum. Afr. J. Agric. Res. 3(6):412-415.

Pemayun, T.G.O. 2009. Induksi estrus dengan PMSG dan GnRH pada sapi perah anestrus postpartum. Buletin Veteriner Udayana. 2(1):1-7.

Prabowo. 2010. Teknik Sinkronisasi Estrus Pada Sapi. Bagian Reproduksi dan Obstetri Fakultas Kedokteran Hewan Universitas Gajah Mada. Yogyakarta

Prihatno, S.A., A. Kusumawati, N.K. Karja and B. Sumiarto. 2013. Profil biokimia darah pada sapi perah yang mengalami kawin berulang. J. Kedokteran Hewan, 7(1):29-31.

Prodanovic, R., D. Kirovski, H, Samanc, I. Vujanac, V. Ivetic, B. Savic, and Kureljusic B. 2012. Estimation of herd-basis energy status in clinically ealthy Holstein cows: practical implications of body condition scoring and hortened metabolic profiles. Afr. J. Agric. Res. (3):418425.

Ribeiro, E.S., R.S. Bisinotto, M.G. Favoreto, L.T. Martins, R.L.A. Cerri, F.T. Silvestre, L.F. Greco, W.W. Thatcher and J.E.P. Santos. 2012. Fertility in dairy cows following presynchronization and administering twice the luteolytic dose of prostaglandin F2 $\alpha$ as one or two injections in the 5-day timed artificial insemination protocol. Theriogenology. 78 (2): 273-284.

Roland, L., M. Drillich and M. Iwersen. 2014. Hematology as a Diagnostic Tool In Bovine Medicine. J. Vet. Diag. Invest. 26(5):592598

Roy, B.B., S. Ghosh, P.K. Pankaj and G. Mandal. 2011. Evaluation of Milk Urea Concentration as Useful Indicator for Dairy Herd Management: A Review. Asian Journal of Animal and Veterinary Advances. 6:1-19.

Saleh, N., E. Mahmud and E. Waded. 2011. Interactions between insulin like growth factor 1, thyroid hormones and blood energy metabolites in cattle with postpartum inactive ovaries. Nat. Sci. 9(5):56-63.

Santosa, B. 2014. Penanggulangan Penyakit Gangguan Reproduksi pada Sapi Potong. Bukittinggi (Indonesia): Balai Veteriner Bukittinggi.

Sennang N, Sulina, A. Badji and Hardjoeno. 2005. Laju filtrasi glomerulus pada orang dewasa berdasarkan tes klirens kreatinin menggunakan persamaan cockroft-gault dan modification of diet in renal disease. Jurnal Medikal Nus.24: 80-84.

Shaka, M., M. Shamesdini and F. MohamadZadeh. 2006. Serum biochemistry values in Raini Goat of Iran. J. Vet. Med. 6(12):3345.

Sianturi, R.G., B. Purwantara, I. Supriatna, Amrozi and P. Situmorang. 2012. Optimasi inseminasi buatan pada kerbau lumpur (bubalus bualis) melalui teknik sinkronisasi estrus dan ovulasi. J. Ilmu Ternak Vet. 17(2):92-99.

Sonjaya, H. 2012. Dasar Fisiologi Ternak. Bogor (ID). Institut Pertanian Bogor.

Steel, R.G.D and J.H. Torrie. 1993. Prinsip dan Prosedur Statistika, Suatu Pendekatan Biometrik. Terjemahan Bambang Sumantri. Gramedia Pustakatama, Jakarta.

Suartini, N.K., I.G.N.B. Trilaksana and T.G.O. Pemayun. 2013. Kadar Estrogen dan Munculnya AEstrus setelah Pemberian Buserelin (Agonis GnRH) pada Sapi Bali mengalami Anestrus Postpartum Akibat Hipofunsi Ovarium. J. Ilmu Kesehatan Hewan. 1(2):40-44.

Suryahadi. 2003. Kajian Teknik Suplementasi Terpadu untuk Meningkatkan Produksi dan Kualitas Susu Sapi Perah di DKI Jakarta. Dalam: Kumpulan Ringkasan Hasil Penelitian Lembaga Penelitian dan Pemberdayaan Masyarakat Institut Pertanian Bogor, Bogor.

Templeman, N.M. and C.T. Murphy. 2018. Regulation of reproduction and longevity by nutrient-sensing pathways. JCB. 217(1):93106.

Torres, X.V., P.L. Morales and J.C. Arango. 2013. The effect of dose and type of cloprostenol on the luteolytic response of dairy cattle during the ovsynch protocol under different oestrous cycle and physiological characteristics. Journal Reproduction in Domest. Anim. 48: 874-880.

Van Saun, R.J. 2000. Blood profiles as indicators of nutritional status. Adv. Dairy Tech. 12:401-410.

Van Zijderveld, S.M., W.J.J. Gerrits, J. Dijkstra, J.R. Newbold, R.B.A. Hulshof and H.B. Perdok. 2011. Persistency of methane mitigation by dietary nitrate supplementation in dairy cows. J. Dairy. Sci. 94:4028-4038 
Vasconcelos, J.T. and M.L. Galyean. 2007. Nutritional recommendations of feedlot consulting nutritionists: The 2007 Texas Tech University Survey. J. Anim. Sci. 85(10):2772-2781.

Vigil, P., M.E. Cortes, A. Zuniga, J. Riquelme and F. Ceric. 2009. Scanning electron and light microscopy study of the cervical mucus in women with polycystic ovary syndrome. J. of Electr. Microscopy. 58(1):21-27.
Wahyudi, L., T. Susilawati and S. Wahjuningsih. 2013. Tampilan Reproduksi Sapi Perah Pada Berbagai Paritas di Desa Kemiri Kecamatan Jabung Kabupaten Malang. J. Ternak Tropikal. 14(2):13-22.

Wardayanto, N. 2004. Penampilan Produksi Domba Domba Lokal Jantan yang Diberi Produk Fermentasi Jerami Padi dengan Ragi Isi Rumen. Thesis. Program Pasca Sarjana Universitas Diponegoro, Semarang. 